\title{
The Influence of Academic Climate and Individual Creativity on Lecturer Competence in Private University at Surabaya Indonesia
}

\author{
Meithiana Indrasari ${ }^{1}$, Peter Newcombe ${ }^{2}$, Anis Eliyana ${ }^{3} \&$ Eddy Yunus $^{4}$ \\ ${ }^{1}$ Economic and Bussiness Faculty University of Dr Soetomo (UNITOMO) Surabaya, Indonesia \\ ${ }^{2}$ Associate Professor, School of Psychology University of Queensland, QLD 4072, Australia \\ ${ }^{3}$ Economic and Bussiness Faculty, Airlangga University Surabaya, Indonesia \\ ${ }^{4}$ Economic and Bussiness Faculty, University of Narotama Surabaya, Indonesia \\ Correspondence: Meithiana Indrasari, Economic and Bussiness Faculty, University of Dr Soetomo (UNITOMO) \\ Surabaya, Indonesia. E-mail: priyono.unu_sidoarjo@yahoo.com
}

Received: May 15, 2015

doi:10.5539/ijbm.v10n8p127
Accepted: June 23, $2015 \quad$ Online Published: July 22, 2015

URL: http://dx.doi.org/10.5539/ijbm.v10n8p127

\begin{abstract}
This research aimed investigated the effect of simultaneous or partial academic climate and creativity lecturer on lecturer competence. Through purposive sampling, 72 tenured faculty who teach management studies courses responded to questions concerning academic climate (relationship, control capabilities and physical environment) and creativity (fluency, flexibility, originality, elaboration and redefinition) and competence (pedagogy, personal, professional, social). , and The results of the regression analysis support all aspects of academic climate and all aspects of creativity lecturer as predictors of competence of lecturers. It can be concluded that the academic climate and creativity affect the competence of lecturers. The results will be discussed in relation to finding improvements in lecturer competence through attention to the academic climate of the institution and the creativity of the lecturer.
\end{abstract}

Keywords: academic climate, individual creativity, competence of lecturer

\section{Introduction}

A lecturer is a professional who manages and guides students in the university environment. They are required to have competence to teach, conduct research, and transform, develop, and disseminate science, technology, and the arts through education, research, and community service (Indonesian law 14/2005 Article 1.2). The Lecturer Competence in Indonesia Law 14/2005 explained that competence is a set of knowledges, skills, and behaviours that must be owned, lived, and controlled by the lecturer in carrying out the duties of their profession. That law is an assessment of the government and informs lecturer performance appraisals which have tended to decline in a quality over the last decade (Drost, 2006).

Djalali (2005) explains that the quality of the work of lecturers in private university is not an accurate assessment when compared with the reality of the task demands of Tri Dharma (three aspects of University lecturer's role Teaching, research, service) in higher education as interest in reading is low and enthusiasm for research activities is still lacking. This is consistent with the views of Drost (2006) and Yeoh, Sze-Yin, and Benjamin (2012), who state that the competence of teachers, with more emphasis on professionalism, is demonstrated through a portfolio. Mujiran (2008) noted that teacher competencies assessed on the deck of a formal administrative compliance certificate do not reflect the internal personal quality of the teaching itself. For that, the Indonesian government sees the need to measure the competence of teachers, especially in higher education, with the goal to improve curriculum teaching, scholarship and training (Suharto, 2011).

Faculty competence assessment should continue to be developed so as the pillars of college professors have a competitive edge and quality to achieve college goals. Based on the research of Cohen (2010) and Tetrick and Eden (2011) concerning the influence of climate on the academic competence of lecturers, and that of Feng and Wood (2012) and Choi, Ibrahim, and Tan (2013) concerning individual creativity related to the competence of lecturers, the purpose of this study is to investigate academic climate and individual creativity as major factors in predicting lecturers competence in a Private University at Surabaya Indonesia. 
Drost (2006) explains that the internal quality of competence can be built through enhanced creative ability. Increased lecturer creativity at university can be achieved by various methods such as providing education and training programs. For Jill and Smith (2006), one of the efforts to improve the competence of lecturers is to encourage creativity. Choi, Ibrahim, and Tan (2013) also suggest that lecturers who have creativity can lead an individual to achieve superior performance.

Suharto (2011) describes the competence of lecturers as creating a conducive academic climate in the classroom. A conducive academic climate is evident with lecturers who have high quality lecturer competence so the university can formulate programs and modern curriculum to ensure the graduates excel and have special qualities. Tetrick and Eden (2011), explains that the academic climate has a role to increase the competence of teachers in the college. They also noted that academic climate is built by improving methods and strategies in lecturer development through fulfilling their field of competence which is based on knowledge, skills and positive work culture. Competence and individual creativities are also linked to the depth of knowledge, skills, and abilities associated with the work, and the skills needed for non-routine work which was also built by the competence of an academic conducive climate.

\section{Lecturer Competence}

Academic competencies, as outlined by Feng and Wood (2012), range from recall and understanding of action and concepts to advanced motor skills, to teaching behaviours and professional values. Yeoh et al. (2012) suggests that competence is a prominent characteristic and covers the ways of behaving and thinking across all situations, and takes place over a long period of time.

In conjunction with educational personnel, competence refers to actions that are rational and satisfy certain certifications in educational tasks. Lecturers require sufficient competencies to perform and carry out their tasks. According to Hergenhahn and Olson (2010) as well as Suparlan (2006), Hong (2010), and Cohen (2010), the concept of competence is the ability to perform the task of teaching and educating acquired through education and training. Rossia, Sirnab, and Tinning (2007) identified that higher education institutions needed teachers who were competent to teach and educate, innovative, creative, had enough time to pursue their professionalism, and were able to maintain authority in the eyes of the students and the community so as to increase the quality of education. Indicators of competence identified in the present study refer to the Indonesia Government Regulation (PP) No.19 of 2005 on Education National Standards article 28 (paragraph 3) which states that the competencies that should be possessed by the teacher as agent of learning are:

a. Pedagogic competence--the ability to manage the learning of students ranging from planning and implementing learning, evaluation, and development potentials.

b. Personal competence--the ability of a stable personality, mature, wise and dignified, exemplary, and noble.

c. Professional competence--the ability of mastery learning materials that enablebroad and deep guiding students

d. Social competence--the ability to communicate and interact effectively with students, fellow educators, staff, parents/guardians of students, and the surrounding communities.

The use of such indicators is considered in accordance with aspects of the competencies used by Feng and Wood (2012), and Choi et al. (2013). The matter of professional competence includes interactive, personality and skills or pedagogical.

\subsection{Academic Climate}

The concept of academic climate is a development from organizational climate (Patricia et al., 2010; William, 2010). Marshall (2002) explained that campus climate is the basis of a condition or state of a learning community. Tetrik and King (2011) later confirmed that the concept of academic climate could be divided into two, namely positive and negative climate. Positive academic climate refers to an atmosphere of tolerance (for differences), egalitarian and resource allocation, while negative academic climate involves a climate of learning, such as intimidation, rough treatment, gender discrimination and disrespectful behavior.

Halpin and Croft (1963, cited in Tubbs \& Garner, 2008) described the climate of the academy as something intangible but important and analogous to an individual's personality. Hoy and Miskel (1987, cited in Pretorius \& Villiers, 2009) described the academic climate as referring to the heart and soul of an academic-the psychological attributes that make academic institutions have a personality, which is relatively resistant and experienced by all members, which explains the collective perceptions of routine behaviour, and will influence the attitudes and behaviour in academic life. 
Scherman (2005) and Gottfredson, Gottfredson, Payne and Gottfredson (2005) provided a similar definition of academic climate, as the quality and intensity of interaction between teachers and students, between teachers themselves, between the leaders of the campus with faculty, between campus leaders and students, between staff with parents and the wider community. Scherman (2005) and Cohen (2010) have proposed measurement indicators for academic climate including:

a. Relationship; which includes integration (cohesion), trust and respect.

b. Control capabilities; the ability to control the relationship in an academic environment, the ability to create a comfortable atmosphere in teaching or applying the rules in an academic environment.

c. Physical environment, involving campus buildings, classrooms, equipment and other physical facilities.

According Hergenhahn and Olson (2010) and others (e.g., Rossia, Sirnab, \& Tinning, 2007) the academic climate in a high risk urban environment shows that a positive, supportive, and culturally conscious climate can lead to significant academic success for urban students in obtaining academic degrees. The researchers also found that a positive academic climate provided protection for a child within a supportive learning environment and prevented anti-social behavior.

\subsection{Individual Creativity}

Creativity can be differentiated into four dimensions; person, process, product and press, known as "the four P's of Creativity" (Taggar, 2004). Based on a factor analysis, Guilford found five properties that characterize creative thinking abilities, namely: fluency, flexibility, authenticity (originality), decomposition (elaboration), and re-formulation (redefinition). In addition, the definition of creativity can be differentiated along consensual and conceptual aspects. A consensual definition emphasizes creative products assessed in terms of degree of creativity by expert observers. In their study, Jill and Smith (2006) described creativity as a form of response that can be assessed by an expert observer. Munandar (2002) describes a consensual definition as based on the following assumptions: a) the creative product or response that can be observed is a manifestation of peak creativity, b) creativity is something that can be recognized by outside observers, c) different degree of creativity, and the observer can come to the agreement that a product is more creative than others. This definition is often used in the fields of science and art where both concern the products, people, processes and the environment where creative people develop their creativity.

A definition of creativity that represents the consensual and conceptual definition was proposed by Stein (Rossia, Sirnab, \& Tinning, 2007), as the creative work is a novel work that is accepted as tenable or useful or satisfying by a group in some point in time. Dimensions of creativity by definition are reflected in criteria such as novel, tenable, useful, and satisfying. On the other hand, a consensual dimension implies that creativity is expressed through words that are accepted by a group in some point in time. A creative personality, according Supriyadi (1999) and Munandar (2002), includes cognitive and non-cognitive factors (interests, attitudes, quality temperamental). Creative people have personality traits that are significantly different from those who are not creative. For Torrance (1988), creativity is the process of feeling and seeing the problems, making educated guesses about the shortage (issue), assessing and testing the conjecture or hypothesis, then changing and testing it again. The most explicit criteria for determining an individual's creativity is referred to as the peak criteria (the ultimate criteria) for creativity. Creativity criteria can be divided into two types, namely based on creative products displayed by a person during their life or when completed a creative work; and based on the concept or definition of creativity being translated into creative behaviour indicator.

Hypothesis Based on the review of research concerning lecturer competence, academic climate and individual creativity, it was hypothesized that academic climate and individual creativity would be positively related to lecturer competence.

\section{Methods}

Participants. This study used a survey method involving 72 Management lecturers in private universities in Surabaya, Indonesia. Participant selection was completed by purposive sampling method, selecting members of the population according to specified criteria (Lawarance \& Lawarance, 2002). These criteria were a lecturer at the college and taught in Management studies. The participants were 40 females and 32 males, aged between $35-53$ years ( $M$ age $=45,25$ years, $S D=9,18)$ and the length of teaching ranged between 5 and 30 years.

Measures. Data were collected through a specifically designed structured questionnaire using a 5-point Likert scale response option, ranging from 1 (completely agree) to 5 (Completely disagree). The scales contained items relating to Competence of the Lecturer (4 sub-scales), Individual creativity (5 sub-scales) and Academic Climate (4 sub-scales). Table 1 provides examples of items from each of these scales. For each of the measures, sub-scale 
scores were computed by averaging responses across the items. For Lecturer Competence, high scores represented 80 for Academic Climate, a high score was indicative of 60 For Individual creativity, high scores represented 75. The participants also responded to demographic questions (e.g., age, gender, work period).

Table 1. Example items for each of the subscales of the lecturer competence, academic climate, and individual creativity measures

\begin{tabular}{|c|c|c|}
\hline Scale & No. of Items & Example Item \\
\hline \multicolumn{3}{|l|}{ Lecturer Competence } \\
\hline Pedagogic & 4 & I catch curiosity of student to give question \\
\hline Personal & 4 & I give an example to student for adhering to university's rule \\
\hline Professional & 4 & I have prepared my teaching material \\
\hline Social & 4 & I try to be active in lecturer organization \\
\hline \multicolumn{3}{|l|}{ Academic Climate } \\
\hline Relationship & 4 & I give positive appreciation to each student who make a paper \\
\hline Control capabilities & 4 & With other lecturer give an example to follow the rule of academic \\
\hline Physical environment & 4 & I concern of the clean room class Individual creativity \\
\hline \multicolumn{3}{|l|}{ Individual creativity } \\
\hline Fluency & 3 & I give many examples/theory application spontaneously \\
\hline Flexibility & 3 & I can accept the students opinion although I don't really understand about it \\
\hline Originality & 3 & I try make my own class material through audio visual \\
\hline Elaboration & 3 & I like to develop class material through variation case examples \\
\hline Redefinition & 3 & I reconclude ideas/my work as a material through for developing \\
\hline
\end{tabular}

Procedures. The process of data collection was completed over ten days at Private universities in Surabaya. Participants completed the paper-and-pencil questionnaire at their universities, individually, and under the guidance of the research team. On average, the questionnaires were completed in 10-15 minutes.

\section{Results}

The first set of analyses sought to determine the strength of the psychometric properties for the newly formed scales of Lecturer Competence, Academic Climate, and Individual Creativity. These analyses included tests of internal consistency (individual item-item correlations, Cronbach's $\alpha$ ). Regression analyses were then conducted to determine whether Lecturer Competence could be reliably predicted from Academic Climate and Individual Creativity. Table 2 contains descriptive data along with inter-item correlations and Cronbach $\alpha$ for all variables of interest. These data show that all inter-item correlations are positive and significant (all $r s \geq 0.25$ ) and that the scale internal consistencies are strong all $\alpha \mathrm{s} \geq 0.92$ ).

Table 2. Descriptive data (means, standard deviations-SD), inter-item correlations, and internal consistencies (Cronbach $\alpha$ ) for all measures and their sub-scales

\begin{tabular}{|c|c|c|c|c|}
\hline Variables & Mean & SD & Inter-Item Correlations & Cronbach $\alpha$ \\
\hline Age (years) & 45,25 & 9,18 & & \\
\hline Work period (years) & 16,01 & 9.47 & & \\
\hline Lecturer competence & 66,82 & 8,29 & & 0.94 \\
\hline Pedagogic & 16,69 & 2,16 & $0.52-0.79$ & \\
\hline Personal & 16,90 & 2,08 & $0.59-0.72$ & \\
\hline Professional & 16,19 & 2,35 & $0.50-0.70$ & \\
\hline Social & 17,03 & 2,31 & $0.60-0.74$ & \\
\hline Academic climate & 50,22 & 5,96 & & 0.92 \\
\hline Relationship & 16,57 & 1,98 & $0.54-0.67$ & \\
\hline Control capabilities & 16,76 & 2,05 & $0.62-0.75$ & \\
\hline Physical environment & 16,89 & 2,31 & $0.62-0.78$ & \\
\hline Individual creativity & 63,01 & 8,00 & & 0.93 \\
\hline
\end{tabular}




\begin{tabular}{llll}
\hline Fluency & 12,61 & 1,80 & $0.66-0.71$ \\
Flexibility & 12,68 & 1,77 & $0.69-0.77$ \\
Originality & 12,35 & 1,67 & $0.51-0.75$ \\
Elaboration & 12,72 & 1,82 & $0.68-0.73$ \\
Redefinition & 12,65 & 1,66 & $0.25-0.80$ \\
\hline
\end{tabular}

The results of the analysis of the correlation between the age (-0.04), gender (-0.02), and tenure (0.02) and each of the focal variables (lecturer Competence, Academic Climate, Individual Creativity) were all non-significant ( $r s \leq 0.05)$. These demographic variables were therefore not included in further analyses.

Table 3. Summary of hypothesis result

\begin{tabular}{lll}
\hline & Value R & Value $\mathrm{R}^{2}$ \\
\hline Model 1 & 0.99 & 0.99 \\
Academid climate & 0.81 & 0.50 \\
Individual creativity & 0.79 & 0.48 \\
\hline
\end{tabular}

Regression analysis was used to determine the effect of climate variables on the academic and creative faculty lecturer competence simultaneously and partially. The results of this hypothesis testing are presented in Table 5 .

Test results signify the hypothesis that there is an influence of climate simultaneously academic and creative faculty to faculty competence has a probability value of less than $1 \%$, so that the hypothesis showed a significant positive effect. Value of the correlation coefficient indicates that the two independent variables, namely the academic climate and creativity lecturers have strong linkages with the competence of lecturers, the effective contribution of $98.6 \%$. Minor hypothesis test results show that the influence of climate on competency academic lecturer has a probability value of $0.000(p<0.05)$. This means that the hypothesis that there is an influence of climate on the academic competence of the faculty can be accepted. The coefficient of determination indicates that the academic climate is able to provide effective contribution of $50.3 \%$ to the increase in the competence of lecturers. Hypothesis that there is an influence on the competence of faculty creativity individual obtained probability value of $0.483(\mathrm{p}<0.05)$. It is proved that the creativity of individuals or lecturer has an influence on the competence of lecturers. Determination coefficient of 0.483 indicates that the creativity of the individual is able to contribute effectively to the improvement of the competence of the lecturers of $48.3 \%$.

For the Ooverall model, academic climate and individual creativity reliably predicted lecturer Competence, $\mathrm{R}^{2}=$ $0.99, \mathrm{~F}(2,69)=2459.09, \mathrm{p}<0.001$. Value Confidence interval on both scales used in data retrieval with over 30 participants (72 participants) showed the range of $.86-.84=0.25(\mathrm{mean}=0.713)$, the accuracy of sampling on a scale of academic climate is at $71,3 \%$ of the 72 samples taken.

There was a significant relationship between the academic climate at faculty and Lecturer Competence, $\beta=0.71$ $(\mathrm{SE}=0.06), 95 \% \mathrm{CI}(0.59 ; 0.84)$. Beta value $(\beta)$ is positive indicating that the academic climate has the same direction as the competence of lecturers, which means when the climate improved academic competence of lecturers will increase at the same rate, which amounted to $71.3 \%$.

There was also a significant relationship between individual creativity and the competence of lecturers, $\beta=0.51$ $(\mathrm{SE}=0.04), 95 \% \mathrm{CI}(0.41 ; 0.60)$. Beta value $(\beta)$ is positive indicating that creativity has the same direction as the competence of lecturers, which means when the climate improved academic competence of lecturers will increase at the same rate, which is $51.1 \%$.

\section{Discussion}

The findings from this research support the hypothesis that lecturer competence can be predicted from academic climate and individual creativity. A more positive academic climate and a more creative individual will lead to greater competence in lecturers. These results are consistent with those of Matzler and Woessmann (2010) and Raza (2011). They show that the academic climate that is supported by a creative teacher will lead to improvements in the competence of lecturers. Choi et al. (2013) also confirmed that teachers who are creative individuals and who are work in an academic environment with a positive climate will enhance the professional competence of teachers.

The results suggest that an academic climate that is open to spur employees to express interest and dissatisfaction without fear of reprisal and attention will enhance lecturer competence. Hoy and Miskel (2001) suggest a 
harmonious academic climate is illustrated by inter-personnel relations, and social and cultural factors that influence the behavior of individuals and groups in an academic environment. It is clear that the academic climate is an important factor in supporting the lecturer performances within a college. Thatcher, Fridjhon, and Cockcroft (2007), and Feng and Wood (2012), explain that the academic atmosphere is expected to support the creation of conditions that are conducive to student learning teams in college to show better performance and then can benefit the wider community, especially if supported by creativity as the spearhead of higher education.

Hong (2010) and Jill and Smith (2006) explored how designers define their own creativity and their decision-making. Their study used a qualitative methodology for explaining the concept of creativity. Reflection of personal skills and competencies emphasized the importance of developing a strong response capabilities and supportive work environment. Hong (2010) concluded that creativity and personality characteristics were associated with continuous learning processes in decision making on design work. Torrance (1988), and Taggar (2004), explain the importance of understanding personal creativity in a reliable and productive designer while also understanding their multi-disciplinary group decision making, because a teacher needs to communicate with others both within and outside the campus. According Hergenhahn, and Olson (2010), the more important is the relationship between creativity better in the design of work processes that occur differently in the decision-making process of individuals who depend on the complexity and nature of the design of the job itself.

The findings add support to Gottfredson et al. (2005), and Hoy and Miskel (2001), who both concluded that the academic climate as the quality of the academic environment that constantly experienced by teachers, affected behaviour. The present results show the influence of individual creativity against the competence of lecturers. According Munandar (1999), there are three pressure capabilities of creativity, related to the ability to combine, solve a problem or answer a reflection of the capabilities and operational. The three pressure capabilities are the ability to create new combinations, based on data, information or elements that exist; ability based on data or information available, find many possible solutions to a problem, where the emphasis is on quality, diversity vandalism and answers; and capabilities that reflect operational fluency, flexibility and originality of thought, and the ability to develop or enrich and detailing an idea.

A strength of this research is that the analysis concentrated on the character of the subject, which is a lecturer, so the results can be used as a reference to efforts to increase the competence of lecturers. A limitation of this research is that the sample was purposively management lecturers, so that the results of relevant research are only applicable to those lecturers. With more research, the findings may be generalized to the entire faculty in higher education.

The results of this study can provide support for follow-up action, that individual creativity is the process of creating a creative idea that has to start from the willingness of the faculty that will assist lecturers to develop their potential. It is important for the creative process at the lecturer is the starting point of renewal where social interaction occurs through creative behavior in the form of recognition and combining diverse ideas to find the best solution. Creativity is the first step that supports the creation of better academic climate, that all of these capabilities relate to the effectiveness of interpersonal relationships in the lives of faculty including relationships with co-workers, and perspectives on campus management system. The development of creative abilities of the lecturer could be a requirement for every faculty to help improve the ability to create an academic climate that is conducive to teaching and learning. Academic climate is important, particularly in the management of behavioral dimensions associated with the relationship between the work environment and teaching behavior, which is related to the tasks for which they are responsible.

\section{References}

Azwar, S. (2010). ValiditasdanReliabilitas. Cetakan 10, Penerbit Pustaka Pelajar, Yogyakarta.

Choi, S. L., Ibrahim, Z., \& Tan, O. K. (2013). An analysis on therelationship between Lecturers' Competencies and Students' Satisfaction. International Education Studies, 7(1), 37-46.

Cohen, J. (2010). Measuring \& improving school climate: a school improvement strategy that supports the whole child and the whole school community. A student services symposium: Supporting Students to Success Harrisburg, PA.

Drost, D. J. (2006). Pendidikan yang Humanis. Jakarta: Penerbit Buku Kompas

Feng, S., \& Wood, M. (2012). What makes a good university lecturer? Students' perceptions of teaching excellence. Journal of Applied Research in Higher Education, 4(2), 142-155. http://dx.doi.org/10.1108/17581181211273110

Gottfredson, G. D., Gottfredson, D. C., Payne, A., \& Gottfredson, N. C. (2005). School climate predictors of 
school disorder: Results from national delinquency prevention in school. Journal of Research in Crime and Delinquency, 42(4), 421-444. http://dx.doi.org/10.1177/0022427804271931

Hergenhahn, B. R., \& Olson, M. H. (2010). Theories of learning (7th ed.). Penerbit: Kencana, Jakarta.

Hong, J. Y. (2010). Pre-service and beginning teachers professional identity and its relation to dropping out of the profession. Teaching and Teacher Education, 26, 1530-1543. http://dx.doi.org/10.1016/j.tate.2010.06.003

Hoy, W. K., \& Miskel, C. G. (2001). Educational Administration: Theory, Research, and Practice. Singapore: McGraw-Hill.

Jill, E., \& Smith, P. (2006). Social yet creative: The role of social relationships in facilitating individual creativity. Academic Management Journal, 49(1), 85-101. http://dx.doi.org/10.5465/AMJ.2006.20785503

Lawarance, N., \& Lawarance, N. J. (2002). Social Research Methods: Qualitative and Quantitative Approaches (7th ed.). St. Matin Press, New York

Marshal, M. L. (2002). Examining School Climate: Defining factors and educational Influences. Center for Research on School Climate and Classroom Management Georgia State University. Artikel Penelitian, Diambil dari. Retrieved from http://education.gsu.edu/schoolsafety/

Matzler, J., \& Woessmann, L. (2010). The Impact of Teacher Subject Knowledge on Student Achievement: Evidence from Within-Teacher Within-Student Variation. Discussion paper series.

Mujiran, P. (2008). Pernak-Pernik Pendidikan. Yogyakarta: Pustaka Pelajar

Munandar, U. (1999). PengembanganKreativitasAnakBerbakat. Depdiknasdan Rineka Cipta, Jakarta.

Munandar, U. (2002). Kreativitas dan Keterbakatan Strategi Mewujudkan Potensi Kreatif dan Bakat. PT Gramedia Pustaka Utama, Jakarta.

Patricia, V. F., Rodríguez, J. A. C., \& Franco, J. S. (2010). Students academic climate perception of the school of business of a Mexican university. American Journal of Business Education, 3(7).

Pretorius. S., \& Villiers, E. D. (2009). Educators' perceptions of school climate and health in selected primary $\begin{array}{lllll}\text { schools. South African Journal of } & \text { Education, }\end{array}$ http://dx.doi.org/10.1590/S0256-01002009000100003

Rossia, T., Sirnab, K., \& Tinning, R. (2007). Becoming a health and physical education (HPE) teacher: Student teacher' performances in the physical education subject department office. Teaching and Teacher Education, 24, 1029-1040. http://dx.doi.org/10.1016/j.tate.2007.11.005

Scherman, V. (2005). School Climate Instrument: A Pilot Study in Pretoria and Environs. Departement Psychology, Faculty of Humanities, University of Pretoria.

Suharto. (2011). Pengembangan Profesionalisme Dosen. Ragam Jurnal Pengembangan Humaniora, 11(1).

Suparlan. (2006). Menjadi Guru Efektif. Yogyakarta: Penerbit Pustaka Pelajar.

Supriadi, D., (1994). Kreativitas, Kebudayaan \& Perkembangan Iptek. Penerbit Alfabeta, Bandung.

Taggar, S. (2004). Individual creativity and group ability to utilize individual creative resources: A multilevel model. Academic Management Journal, 45(2), 315-330. http://dx.doi.org/10.2307/3069349

Tetrick, L., \& Eden, K. (2011). Academic Climate Survey. Technical Report, Rice University, Houston, United State.

Torrance, E. P. (1988). The Nature of Creativity As Manifest In Its Testing. In R. J. Sternberg (Ed.), The Nature of Creativity. Cambridge, England: Cambridge Univ. Press.

Tubbs, J. E., \& Garner, M. (2008). The impact of school climate on school outcomes. Journal of College Teaching \& Learning, 5(9), 17-26.

William, D. A. (2010). Campus Climate and Culture Study. Final Report, Centre for Strategi Leadership \& Change, Inc.

Yeoh, S. F., Jessica, H. S. Y., \& Benjamin, C. Y. F. (2012). Student Evaluation of Lecturer Performance Among Private University Students. Canadian Social Science, 8(4), 238-243. 


\section{Copyrights}

Copyright for this article is retained by the author(s), with first publication rights granted to the journal.

This is an open-access article distributed under the terms and conditions of the Creative Commons Attribution license (http://creativecommons.org/licenses/by/3.0/). 